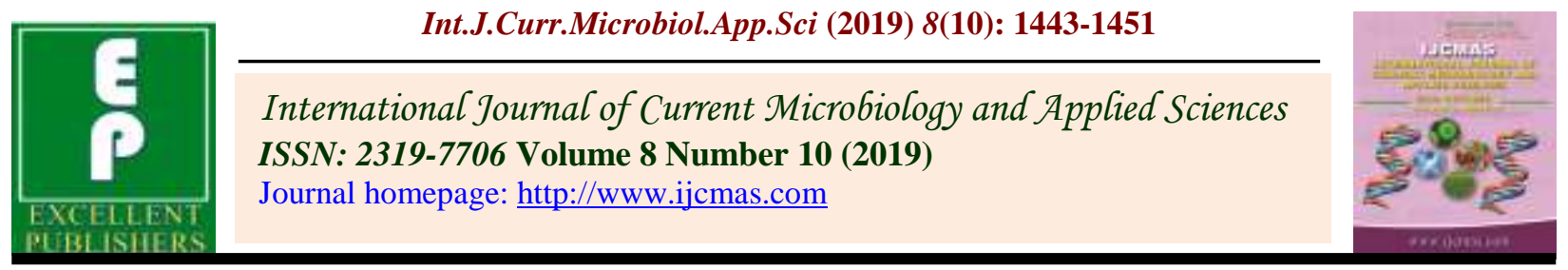

Original Research Article

https://doi.org/10.20546/ijcmas.2019.810.169

\title{
Effect of Increasing Elevation of Lowland Coastal Saline Soil of the Sundarbans Delta on Soil Organic Carbon, its Fractions and Nutrients Availability
}

\author{
Tonmoy Sengupta $^{1 *}$, B. K. Bandyopadhyay ${ }^{2}$ and Sudipta Tripathi ${ }^{1}$ \\ ${ }^{1}$ Department of Agricultural Chemistry and Soil Science, Institute of Agricultural Science, \\ University of Calcutta, 51/2 Hazra road, Kolkata-700019 West Bengal, India \\ ${ }^{2}$ Emeritus Scientist (ICAR), ICAR-Central Soil Salinity Research Institute, Regional Research \\ Station, Canning Town- 743329, West Bengal, India \\ *Corresponding author
}

\begin{tabular}{|l|}
\hline Ke y w o r d s \\
Coastal saline soil, \\
$\begin{array}{l}\text { Sundarban, Raising } \\
\text { land elevation, } \\
\text { Permanganate } \\
\text { oxidisable carbon }\end{array}$ \\
\hline Article Info \\
\hline $\begin{array}{l}\text { Accepted: } \\
\text { 12 September } 2019 \\
\text { Available Online: } \\
\text { 10 October } 2019\end{array}$ \\
\hline
\end{tabular}

Keywords

Coastal saline soil, Sundarban, Raising land elevation, Permanganate oxidisable carbon

\section{A B S T R A C T}

The delta region of India and Bangladesh is popularly known as Sundarbans. Agricultural productivity of the region is very poor due to higher soil salinity and poor drainage due to presence of brackish ground water table at shallow depth. Increasing land elevation through land shaping has showed to increase in crop productivity. The original lands remained waterlogged for about five months (July to November) in a year while elevated lands were never waterlogged. Soil samples were collected from uplands and adjacent original lowlands from eight different field locations in three different seasons (winter, summer and late summer) for two years. Results depicted that there was a considerable change in fertility status due to conversion of lowlands into uplands. Soil salinity decreased after changing land elevation to a great extent. Soil organic carbon (SOC) was higher in lowland situation, but permanganate oxidisable carbon (POXC) \& microbial biomass carbon (MBC) was significantly higher in upland situation than lowlands. Phosphorus availability increased after increasing land elevation. Potassium and micronutrient availability was higher in lowland situations compared to upland situation.

\section{Introduction}

The delta region of the river Ganges is spread over India and Bangladesh is popularly known as Sundarbans. The Indian Sundarbans is dominately present in the North and South 24
Parganas districts of West Bengal. Agricultural lands in this area are mostly lowlands and saline due to presence of brackish ground water table at shallow depth. The productivity of these lands is extremely poor. Increasing elevation of these lands 
through land shaping has shown considerable improvement in productivity (Bandyopadhyay et al., 2009). It is well known that fertility status of soil is one of the best indicators of soil productivity besides its physical and chemical properties. Availability of sufficient quantities of macro and micro nutrients in soil along with soil organic carbon and its active fractions are important components of soil fertility (NRCCA, 2016). Soil organic carbon (SOC) greatly influences physical, chemical and biological properties of soil or soil quality (Canqui et al., 2013) and its productivity. The active fraction of SOC is rather more important than total SOC in influencing soil quality (Bezdicek et al., 1996). Weil et al., (2003) opined that active fraction of soil organic carbon as determined by permanganate oxidizable carbon (POXC) was important for soil quality. Cotton and Wilkinson (1965) postulated that determination of permanganate oxidizable organic carbon is one of the innovative methods that can indicate better soil health. Several other researchers (Cambardella and Elliott, 1992; Wardle, 1992) observed that microbial biomass carbon (MBC) in soil was a major indicator of soil quality which changed with management practices such as tillage, cover crops, land use etc. Bhatt and Banmeru (2014) reported that microbial biomass carbon accounted for only $1-3 \%$ of SOC but it was the eye of needle through which all material that enters the soil must pass. Nielsen and Winding (2002) postulated that MBC was the most commonly used indicators for monitoring microbiological health of soil. Tripathi et al., (2006) observed a decrease in $\mathrm{MBC}$ with a rise of soil salinity and opined that soil salinity was one of the reasons for poor soil health and productivity of coastal saline soils of Sundarbans. Adverse effect of soil salinity was also observed in availability of nitrogen and phosphorus in soil (Grattan \& Grieve, 1999). Effect of land shaping on soil quality and its fertility status is rarely studied.
Thus focus of this study was to evaluate the changes occurred in soil on conversion of lowland coastal soil of Sundarbans into upland in respect of its organic carbon, its fractions and available nutrients.

\section{Method and Materials}

\section{Study area}

The study area falls under Basanti and Canning block in Sundarbans of West Bengal (Fig. 1) in the district of South 24 Parganas $\left(88^{\circ} 2^{\prime} 14^{\prime \prime}\right.$ and $89^{\circ} 4^{\prime} 34^{\prime \prime}$ E latitude and $21^{\circ}$ $31^{\prime} 51^{\prime \prime}$ and $23^{\circ} 13^{\prime} 3^{\prime \prime} \mathrm{N}$ longitude). The study area falls under coastal agro-eco-region (no. 18.5) of India.

\section{Soil collection}

Soil samples were collected from 8 different upland and adjacent lowland field locations (Nos.1 to 8), where uplands were created on conversion a part of adjacent lowlands at least ten years back through land shaping with the assumption that upland soils had reasonably stabilized. The detail of land shaping technology was described by Bandyopadhyay et al., (2009). Conversion of lowlands into uplands primarily constituted digging of a portion of lowland and raising the elevation of the remaining farm land by about $1 \mathrm{~m}$. Precaution were taken to spread $0-30 \mathrm{~cm}$ soil of original lowland on the top of the raised lands. Lowlands were usually mono cropped and followed rice (in monsoon season) fallow crop rotation and uplands followed multi crop cultivation (vegetable-vegetable/ field crops). Soil samples were collected from upper $30 \mathrm{~cm}$ soil layer of uplands (U) and adjacent lowlands (L) in three different seasons' viz. winter (December-January), summer (March-April) and late summer (May-June) for two consecutive years. The soil samples were air dried, ground, passed through a $2 \mathrm{~mm}$ sieve for various physico- 
chemical analyses. Fresh soil samples were stored in refrigerator for soil microbial biomass carbon (MBC) analysed within quickest possible period as stipulated in the method.

\section{Analytical procedure}

Soil salinity (ECe) was analysed from saturation paste extract of soil. Soil organic carbon (SOC) and available nutrients in soil was estimated by standard methods as described by Tandon (1998). Permanganate oxidisable organic carbon (POXC) was estimation by $\mathrm{KMnO}_{4}$ extraction method as described by Weil et al., (2003). MBC was estimated by the fumigation extraction method according to Vance et al., (1987). For soil moisture analysis samples were collected separately from 0-10, 10-20, 20-30, 30-50, 5070 and 70-90 cm and estimated gravimetrically. IBM SPSS var. 22.0 was used all data analysis. Duncan's multiple range test at $0.05 \mathrm{P}$ was used for determining significant of differences.

\section{Results and Discussion}

The salinity of the soil reduced considerably on raising elevation (Table 1) of lowlands i.e. on conversion of lowlands into uplands. This might be due to the fact that distance between surface of uplands and the brackish groundwater table. The salinity (ECe) of lowlands was $7.84 \mathrm{dSm}^{-1}$ while that of adjacent uplands were $4.02 \mathrm{dSm}^{-1}$ in late summer season (Fig. 2). Salinity of soil showed considerable seasonal variability, being minimum in monsoon season and maximum in late summer season. Seasonal variation of soil salinity was also previously reported by Yadav et al., (1979).

Soil organic carbon (SOC) significantly differed between land situations (Table 3). In general SOC was higher in original lowland situation than upland soils (except plot no 5 which was under orchard) (Table 3). Regular leaf fall and shed effect might have contributed to higher soil organic carbon in upland of plot no 5. Higher soil organic carbon in orchard was also previously reported by Sevgi \& Tecimen (2008). Lower rate of decomposition in lowlands might have due to high moisture content (Table 2) and higher soil salinity led high soil organic carbon in lowlands, thus lower microbial activity.

Lyon et al., (2011) and Sahrawat (2004) also reported higher SOC in lowlands with ground water table at shallow depth. For both uplands and lowlands there was a declining trend of SOC with progress of seasons from winter to late summer (Fig. 3).

Table.1 Soil salinity (ECe dS $\mathrm{m}^{-1}$ ) at different farm location in upland and lowland situation compiled over seasons and years

\begin{tabular}{|c|c|c|c|c|c|c|c|c|c|}
\hline Land situation & \multicolumn{7}{|c|}{ Field location } & Mean \\
\cline { 2 - 10 } & 1 & 2 & 3 & 4 & 5 & 6 & 7 & 8 & \\
\hline $\mathbf{U}$ & $2.5^{\mathrm{a} 1}$ & $3.0^{\mathrm{a} 2}$ & $4.5^{\mathrm{a} 3}$ & $2.5^{\mathrm{a} 4}$ & $2.4^{\mathrm{a} 5}$ & $3.5^{\mathrm{a} 6}$ & $2.5^{\mathrm{a} 7}$ & $6.8^{\mathrm{a} 8}$ & $3.5^{\mathrm{a}^{*}}$ \\
\hline $\mathbf{L}$ & $4.2^{\mathrm{b} 1}$ & $5.3^{\mathrm{b} 2}$ & $5.7^{\mathrm{b} 3}$ & $7.1^{\mathrm{b} 4}$ & $7.1^{\mathrm{b} 5}$ & $6.5^{\mathrm{b} 6}$ & $7.9^{\mathrm{b} 7}$ & $12.4^{\mathrm{b} 8}$ & $7.0^{\mathrm{b}}$ \\
\hline
\end{tabular}

*Figures denoted by different alphabets under the same field locations (1 to 8 ) were statistically different at 5\% probability level by DMRT. Comparison only among the different field locations (1 to 8 ) 
Table.2 Soil moisture (\%) in different seasons at different field locations in upland and lowland situations

\begin{tabular}{|c|c|c|c|c|c|c|c|}
\hline \multirow{2}{*}{ Season } & Land & \multicolumn{7}{|c|}{ Soil depth } \\
\cline { 2 - 8 } & situation & $0--10$ & $10--20$ & $20--30$ & $30-50$ & $50-70$ & $70-90$ \\
\hline \multirow{2}{*}{ Winter } & $\mathrm{U}$ & 29.9 & 27.6 & 26.5 & 26.8 & 32.7 & 40.2 \\
\cline { 2 - 8 } & $\mathrm{L}$ & 38.9 & WT & WT & WT & WT & WT \\
\hline \multirow{2}{*}{ Summer } & $\mathrm{U}$ & 23.0 & 22.0 & 18.5 & 18.3 & 20.7 & 28.2 \\
\cline { 2 - 8 } & $\mathrm{L}$ & 29.1 & 30.9 & 33.8 & WT & WT & WT \\
\hline \multirow{2}{*}{$\begin{array}{c}\text { Late } \\
\text { summer }\end{array}$} & $\mathrm{U}$ & 23.6 & 25.5 & 24.8 & 22.6 & 21.2 & 19.1 \\
\cline { 2 - 8 } & $\mathrm{L}$ & 30.2 & 28.1 & 27.5 & 32.0 & WT & WT \\
\hline
\end{tabular}

Table.3 OC, POXC, MBC and nutrient availability at different farm locations in upland (U) and lowland (L) situations compiled over seasons and years

\begin{tabular}{|c|c|c|c|c|c|c|c|c|c|c|}
\hline \multirow[t]{2}{*}{ Soil properties } & \multirow{2}{*}{$\begin{array}{c}\text { Land } \\
\text { situations }\end{array}$} & \multicolumn{8}{|c|}{ Farm Location } & \multirow[t]{2}{*}{ Mean } \\
\hline & & 1 & 2 & 3 & 4 & 5 & 6 & 7 & 8 & \\
\hline \multirow{2}{*}{$\begin{array}{l}\text { OC } \\
(\text { g C kg soil } \\
\text {-1) }\end{array}$} & $\mathbf{U}$ & 11.6 & 11.9 & 8.6 & 9.7 & 14.4 & 12.7 & 9.0 & 13.1 & $11.4^{\mathrm{a} *}$ \\
\hline & $\mathbf{L}$ & 13.0 & 14.5 & 10.1 & 13.6 & 13.6 & 14.5 & 14.3 & 13.7 & $13.4^{\mathrm{b}}$ \\
\hline \multirow{2}{*}{$\begin{array}{l}\text { POXC } \\
\left(\text { g kg soil }^{-1}\right)\end{array}$} & $\mathbf{U}$ & 0.30 & 0.34 & 0.27 & 0.27 & 0.56 & 0.34 & 0.36 & 0.57 & $0.38^{\mathrm{a}}$ \\
\hline & $\mathbf{L}$ & 0.26 & 0.32 & 0.24 & 0.23 & 0.23 & 0.31 & 0.34 & 0.42 & $0.29^{b}$ \\
\hline \multirow{2}{*}{$\begin{array}{l}\text { MBC }\left(\mu \mathrm{g} \mathrm{C} \mathrm{g-}{ }^{1}\right. \\
\text { oven dry soil h- }{ }^{1} \\
\left.\text { at } 37^{\circ} \mathrm{C}\right)\end{array}$} & $\mathbf{U}$ & 54.1 & 84.8 & 80.5 & 79.8 & 93.8 & 240.9 & 131.7 & 318.5 & $135.5^{\mathrm{a}}$ \\
\hline & $\mathbf{L}$ & 39.6 & 72.2 & 77.3 & 59.3 & 59.3 & 153.3 & 107.8 & 165.2 & $91.8^{\mathrm{b}}$ \\
\hline \multirow{2}{*}{$\begin{array}{l}\text { Avail. } \mathbf{N} \\
\left(\mathrm{kg} \mathrm{ha}^{-1}\right)\end{array}$} & $\mathbf{U}$ & 171.8 & 179.1 & 169.1 & 140.7 & 221.2 & 160.7 & 162.8 & 185.4 & $173.8^{\mathrm{a}}$ \\
\hline & $\mathbf{L}$ & 148.7 & 189.4 & 154.9 & 201.4 & 201.4 & 142.6 & 171.9 & 161.2 & $171.4^{\mathrm{a}}$ \\
\hline \multirow[t]{2}{*}{ Avail. $P\left(k_{g ~ h a}{ }^{-1}\right)$} & $\mathbf{U}$ & 13.4 & 18.1 & 12.0 & 19.9 & 23.0 & 8.8 & 17.1 & 10.0 & $15.3^{\mathrm{a}}$ \\
\hline & $\mathbf{L}$ & 4.8 & 4.9 & 4.9 & 3.2 & 3.2 & 4.6 & 3.5 & 6.9 & $4.5^{b}$ \\
\hline \multirow[t]{2}{*}{ Avail. K(kg ha $\left.{ }^{-1}\right)$} & $\mathbf{U}$ & 876.7 & 793.0 & 890.7 & 1032.3 & 1007.3 & 558.6 & 543.1 & 617.1 & $789.9^{\mathrm{a}}$ \\
\hline & $\mathbf{L}$ & 887.4 & 863.2 & 933.7 & 1044.3 & 1044.3 & 661.8 & 636.6 & 740.8 & $851.5^{b}$ \\
\hline \multirow[t]{2}{*}{ Fe (ppm) } & $\mathbf{U}$ & 76.5 & 112.6 & 82.9 & 93.7 & 120.4 & 127.7 & 75.1 & 65.8 & $94.3^{\mathrm{a}}$ \\
\hline & $\mathbf{L}$ & 163.7 & 214.7 & 142.3 & 222.4 & 222.4 & 215.4 & 183.4 & 112.6 & $184.6^{\mathrm{b}}$ \\
\hline \multirow[t]{2}{*}{ Zn (ppm) } & $\mathbf{U}$ & 3.2 & 7.1 & 7.0 & 3.2 & 6.4 & 3.6 & 4.0 & 2.3 & $4.6^{\mathrm{a}}$ \\
\hline & $\mathbf{L}$ & 4.2 & 2.8 & 4.8 & 3.2 & 3.2 & 3.6 & 4.0 & 1.9 & $3.5^{\mathrm{a}}$ \\
\hline \multirow[t]{2}{*}{$\mathrm{Cu}(\mathbf{p p m})$} & $\mathbf{U}$ & 8.9 & 11.8 & 8.5 & 10.5 & 12.3 & 12.0 & 9.0 & 9.3 & $10.3^{\mathrm{a}}$ \\
\hline & $\mathbf{L}$ & 15.0 & 16.0 & 14.8 & 19.0 & 19.0 & 17.0 & 15.5 & 13.0 & $16.2^{\mathrm{b}}$ \\
\hline \multirow[t]{2}{*}{ Mn (ppm) } & $\mathbf{U}$ & 53.6 & 37.4 & 60.2 & 55.9 & 63.1 & 34.6 & 40.6 & 61.0 & $50.8^{a}$ \\
\hline & $\mathbf{L}$ & 106.8 & 84.1 & 102.2 & 99.7 & 99.7 & 64.9 & 71.4 & 121.1 & $93.7^{b}$ \\
\hline
\end{tabular}

* Figures denoted by same alphabets under same soil properties were statistically at per at $5 \%$ probability level by DMRT 
Fig.1 Map of coastal region of Sundarban

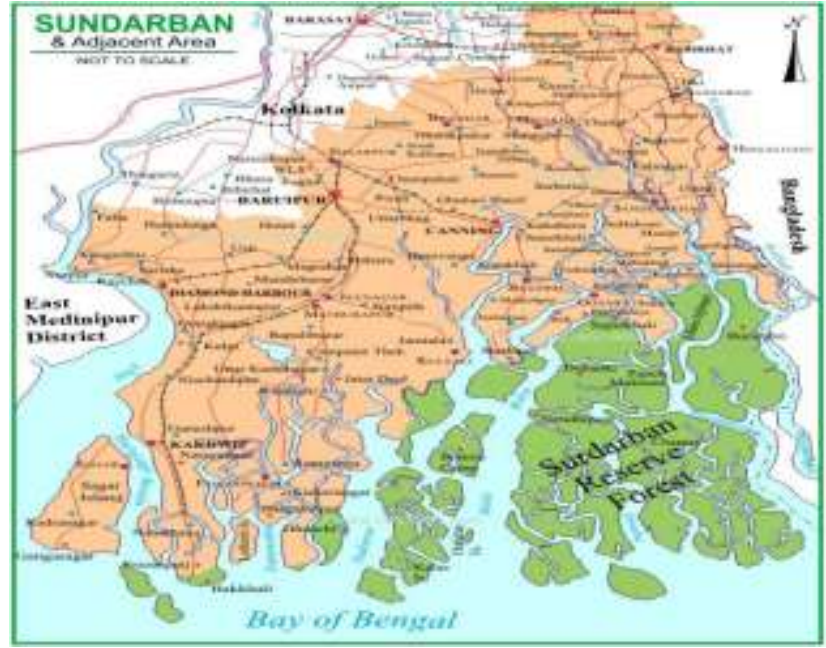

Fig.2 Soil salinity of uplands and lowlands at different seasons compiled over field location and years

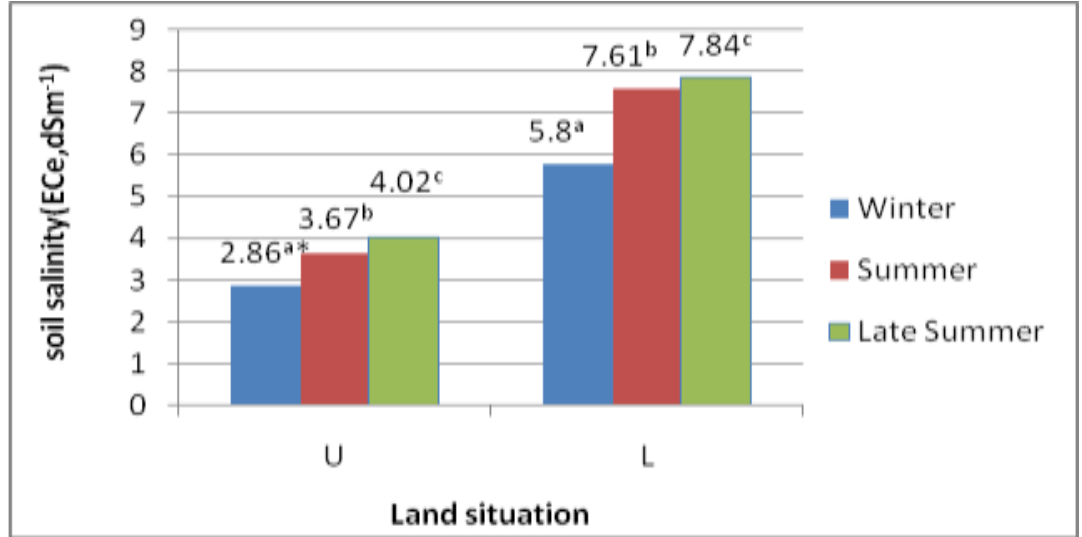

Figures denoted by different alphabets under the same land situations (upland/lowland) were statistically different at 5\% probability level by DMRT

Fig.3 Soil organic carbon ( $\mathrm{g} \mathrm{C} \mathrm{kg} \mathrm{soil}{ }^{-1}$ ) in different season at upland and lowland situation compiled over field locations and years

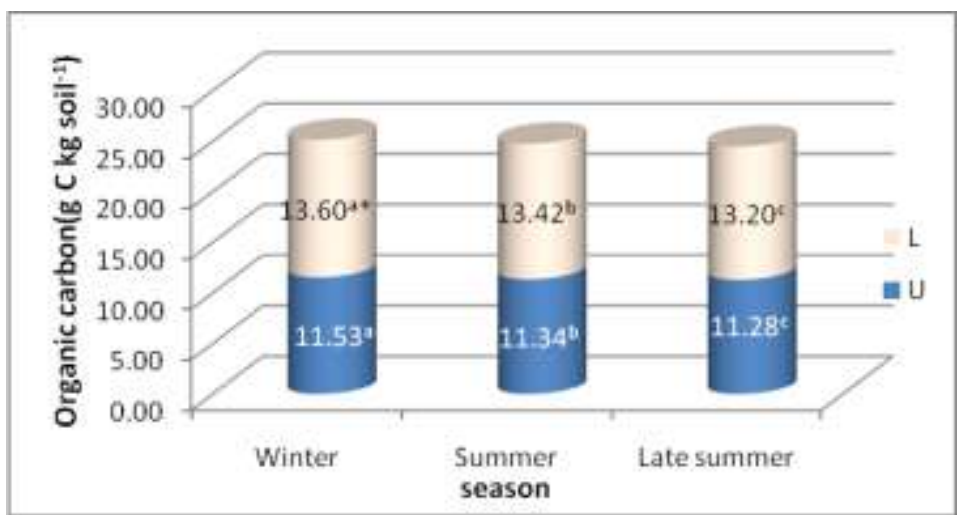

* Figures denoted by different alphabets under different land situation (upland/lowland) were statistically different at $5 \%$ probability level by DMRT 
Fig.4 POXC (g kg soil $\left.{ }^{-1}\right)$ in different season at upland and lowland situation compiled over field locations and years

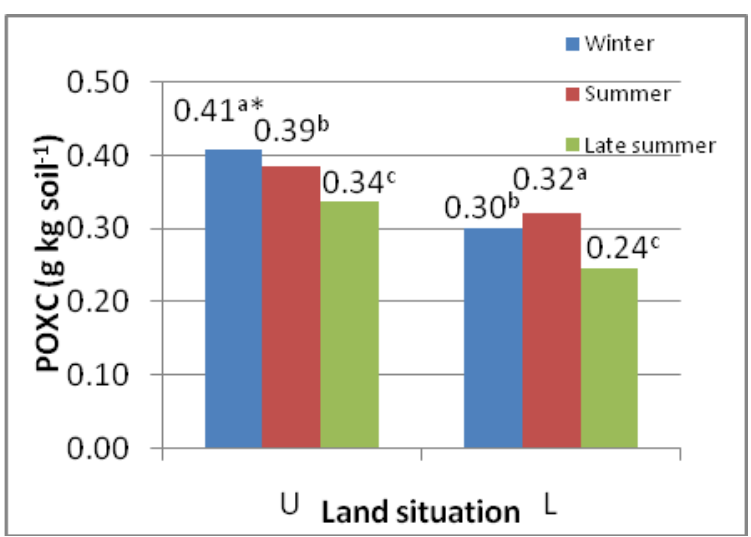

* Figures denoted by different alphabets under different land situation (upland/lowland) were statistically different at $5 \%$ probability level by DMRT

Fig.5 MBC ( $\mu \mathrm{g} \mathrm{C} \mathrm{g}^{-1}$ oven dry soil $\mathrm{h}^{-1}$ at $\left.37^{\circ} \mathrm{C}\right)$ in different season at upland and lowland situation compiled over field locations and years

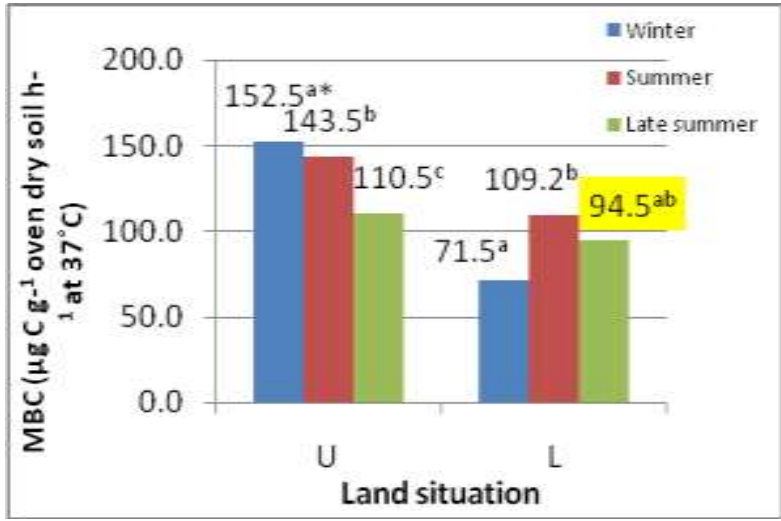

* Figures denoted by different alphabets under different land situation (upland/lowland) were statistically different at $5 \%$ probability level by DMRT

Soil labile C like POXC and MBC fractions of SOC were significantly correlated $(r=0.65)$. Labile organic carbon (LOC) was significantly higher in upland situation than in adjacent lowland (Table 3). There were higher LOC in orchard and agro-forestry fields compared to plots with vegetable crops. LOC was higher in uplands compared to corresponding adjacent lowlands. In upland situations average POXC and $\mathrm{MBC}$ were higher in winter season and those decreased with progress of season from summer to late summer. While, in lowlands
POXC and MBC increased slightly form winter to summer and then decreased in late summer season (Fig. 4 and 5). Relatively lower content of POXC and MBC in winter season in lowland soils might be due to lower rate of decomposition of SOC due to high soil moisture condition (Table 2). Lower soil salinity and higher aeration in uplands might have resulted higher microbial activity and consequently higher content of LOC. Non congenial soil condition in respect of salinity and temperature in late summer season might 
have reduced microbial activity in soil resulting reduced LOC in both uplands and lowlands.

This result indicated higher LOC in upland soils in spite of its lower SOC compared to lowland. On the other hand, agricultural productivity was higher in upland situation (Bandyopadhyay et al., 2009). This indicated that labile pool of SOC can be a better indicator of soil quality or productivity rather than SOC itself. Our result supports the earlier observation of Wang et al., (2005) who concluded that POXC provided better qualitative characterization of SOC to reflect its sensitivity to environmental changes. Soil may have higher SOC but it may or may not contain higher LOC.

The soils were generally low in available $\mathrm{N}$ and $\mathrm{P}$ but high in available $\mathrm{K}$ and micronutrients like iron $(\mathrm{Fe})$, cupper $(\mathrm{Cu})$, zinc $(\mathrm{Zn})$ and manganese $(\mathrm{Mn})$ (Table 3) as also observed by Burman et al., (2019). Nitrogen and phosphorus availability in soil were lower in original lowland soils than in uplands, whereas potassium availability was higher in low lands although it was quite high in both upland and low lands (Table 3). Seasonal effect revealed that nitrogen and phosphorus availability decreased and potassium availability increased with progress of seasons from winter to late summer. The available potassium content of soil was also related to increase in soil salinity as potassium is a constituent of salts in soil (Bandyopadhyay et al., 2003). Positive Significant correlation was observed between available nitrogen with POXC ( $\mathrm{r}=0.62)$ and between available phosphorus and MBC $(\mathrm{r}=0.55)$, which indicated increase in available $\mathrm{N}$ and $\mathrm{P}$ with increase in LOC in soil. Micronutrients like $\mathrm{Fe}, \mathrm{Mn}$ and $\mathrm{Cu}$ availability in soil were higher in lowlands whereas $\mathrm{Zn}$ availability was higher in uplands.
The results of the study revealed that:-

Increase in land elevation of coastal saline soils of Sundarbans showed considerable impact on labile organic carbon fraction (POXC and MBC) of soil.

Labile fraction of soil organic carbon was higher in uplands than in lowlands although SOC was higher in lowlands.

Increase elevation of coastal saline soils also showed considerable influence on available nutrients in soil.

There was an increase in $\mathrm{P}$ availability and decrease in micronutrient availability (except $\mathrm{Zn}$ ) on conversion of lowland into upland.

\section{Acknowledgement}

The authors are grateful to the Indian Council of Agricultural Research, New Delhi, for financial support for conducting the study under Emeritus Scientist Scheme. The authors also grateful to the Director, ICAR-Central Soil Salinity Research Institute, Karnal, Haryana and the Head, ICAR- Central Soil Salinity Research Institute Regional Research Station, Canning Town, West Bengal for providing all necessary logistic facilities for the work. The authors are also highly thankful to the Director, Institute of Agricultural Science, University of Calcutta for extending laboratory facilities at Baruipur Farm.

\section{References}

Bandyopadhyay, B. K., Burman, D., Sarangi, S. K., Mandal, S. and Bal, A. R. 2009. Land shaping techniques to alleviate salinity and water logging problems of mono-cropped coastal land for MultiCrop Cultivation. J. Indian Soc. Coastal agric. Res. 27(1): 13-17.

Bandyopadhyay, B. K., Maji, B., Sen, H. S. 
and Tyagi, N.K. 2003. Coastal Soils of West Bengal -Their Nature, Distribution and Characteristics, Bulletin No. 1/2003. Central Soil Salinity Research Institute, Regional Research Station, Canning Town, West Bengal, India. Pp. 62.

Bezdicek, D. F., Papendick, R.I. and Lal, R. 1996. Introduction: importance of soil quality to health and sustainable land management. In: Methods of Assessing Soil Quality (Eds.: J.W. Doran and A.J. Jones). SSSA Spec. Publ. 49, Madison. Pp.18.

Bhatt, M. and Banmeru, S. 2014. Estimates of soil microbial biomass carbon of forest soil types of Gujarat, India. Int. J. Curr. Microbiol. App. Sci. 3(11): 817825.

Burman D., Mondal M.K., Khan Z.H., Sutradhar A.K., Kamal F.A. 2019. Soil and Water Resources of Sundarbans. In: Sen H. (eds) The Sundarbans: A Disaster-Prone Eco-Region. Coastal Research Library, vol 30. Springer, Cham. Pp. 165-198.

Cambardella, C.A., and Elliot, E.T. 1992. Particulate soil organic matter changes across a grassland cultivation sequence. Soil Sci. Soc. Am. J. 56, 777-783.

Canqui, H. B., Shapiro, C. A., Wortmann, C. S., Drijber, R. A., Mamo, M., Shaver, T. M., and Ferguson, R. B. 2013. Soil organic carbon: The value to soil properties. J. of Soil and Water Cons. 68(5): 129-134.

Cotton, F.A., and Wilkinson, G. 1965. Advanced Inorganic Chemistry. 4th ed. Inter Science Publishers, John Wiley and Sons, New York. Pp. 839-840.

Grattan, S. R. and Grieve, C. M. 1999. Salinity-mineral nutrient relations in horticultural crops. Scientia Horticulturae. 78, 127-157.

Lyon, S. W., Grabs, T., Laudon, H., Bishop,
K. H. and Seibert, J. 2011. Variability of groundwater levels and total organic carbonin the riparian zone of a boreal catchment. J. of Geophysical Res. 116, $1-12$.

Nielsen, M.N. and Winding, A. 2002. Microorganisms as indicators of soil health. National Environment Research Institute. Technical Rep. No. 338. Denmark.

NRCCA, 2016. Soil Fertility \& Nutrient Management -Study Guide, 1-42. http://nmsp.cals.cornell.edu/publicatio ns/extension/NRCCA_Manual_Nutrie nt_Management_10_26_2016.pdf.

Sahrawat K. L., 2004. Organic matter accumulation in submerged soils. $A d v$ Agron. 81, 169-201.

Sevgi, O. and Tecimen, H.B. 2008. Changes in Austrian Pine forest floor properties in relation with altitude in mountainous areas. J. Forest Sc. 54, 306-313.

Tandon, H.L. S. 1998. Methods of analysis of soils, plants, waters and fertilizer. Fertilizers development and consultation organisation, New Delhi, India. Pp. 1-144.

Tripathi, S., Kumari, S., Chakraborty, A., Gupta, A., Chakrabarti, K. and Bandyopadhyay, B. K. 2006. Microbial biomass and its activities in salt-affected coastal soils. Biol Fertil Soils. 42, 273-277.

Vance, E. D., Brookes, P. C., and Jenkinson, D. S. 1987. An extraction method for measuring soil microbial biomass $\mathrm{C}$. Soil Biol. Biochem. 19, 703-707.

Wang, S., Zhou, G., Gao, S. and Guo, J. 2005. Soil organic carbon and labile carbon along a precipitation gradient and their responses to some environmental changes. Pedosphere. 15 (5): 676-680.

Wardle, D.A., 1992. A comparativeassessment of factors which influence microbial biomass carbon and nitrogen 
levels in soil. Biolog. Rev. Cambridge Philos. Soc. 67, 321-358.

Weil, R.R., Islam, K.R., Stine, M.A., Gruver, J.B., and Samson-Liebig, S.E. 2003. Estimating active carbon for soil quality assessment: A simplified method for laboratory and field use. Am. J. Altern. Agric. 18, 3-17. doi:10.1079/ AJAA2003003. Yadav, J. S. P., Bandyopadhya, A. K., Rao, K. V. G. K., Sinha, T. S. and Biswas, C. R. 1979. Coastal saline soil of India. Central Soil Salinity Research Institute (ICAR) Kamal, 132001, India. Bulletin no. 5. 1-33.

\section{How to cite this article:}

Tonmoy Sengupta, B. K. Bandyopadhyay and Sudipta Tripathi. 2019. Effect of Increasing Elevation of Lowland Coastal Saline Soil of the Sundarbans Delta on Soil Organic Carbon, its Fractions and Nutrients Availability. Int.J.Curr.Microbiol.App.Sci. 8(10): 1443-1451. doi: https://doi.org/10.20546/ijcmas.2019.810.169 